\title{
Azospirillum: benefits that go far beyond biological nitrogen fixation
}

\author{
Josiane Fukami ${ }^{1,2}$, Paula Cerezini ${ }^{1}$ and Mariangela Hungria ${ }^{1,2^{*}}$ (D)
}

\begin{abstract}
The genus Azospirillum comprises plant-growth-promoting bacteria (PGPB), which have been broadly studied. The benefits to plants by inoculation with Azospirillum have been primarily attributed to its capacity to fix atmospheric nitrogen, but also to its capacity to synthesize phytohormones, in particular indole-3-acetic acid. Recently, an increasing number of studies has attributed an important role of Azospirillum in conferring to plants tolerance of abiotic and biotic stresses, which may be mediated by phytohormones acting as signaling molecules. Tolerance of biotic stresses is controlled by mechanisms of induced systemic resistance, mediated by increased levels of phytohormones in the jasmonic acid/ethylene pathway, independent of salicylic acid (SA), whereas in the systemic acquired resistance-a mechanism previously studied with phytopathogens-it is controlled by intermediate levels of SA. Both mechanisms are related to the NPR1 protein, acting as a co-activator in the induction of defense genes. Azospirillum can also promote plant growth by mechanisms of tolerance of abiotic stresses, named as induced systemic tolerance, mediated by antioxidants, osmotic adjustment, production of phytohormones, and defense strategies such as the expression of pathogenesis-related genes. The study of the mechanisms triggered by Azospirillum in plants can help in the search for more-sustainable agricultural practices and possibly reveal the use of PGPB as a major strategy to mitigate the effects of biotic and abiotic stresses on agricultural productivity.
\end{abstract}

Keywords: Plant growth promoting bacteria, PGPB, Inoculant, Induced systemic resistance, Systemic acquired resistance, Induced systemic tolerance

\section{Introduction}

Projections of population increases, especially in developing countries, as well as of life expectancy worldwide, imply greater needs for food and feed (FAO 2009). To achieve higher productivity, agriculture is being intensified, mainly with monocultures highly dependent on increased chemical inputs, including pesticides and fertilizers (McArthur and McCord 2017; Roser and Ritchie 2017). However, to ensure long-term food production, we must develop sustainable agricultural practices, based on conservationist practices, to achieve economic returns for farmers, but with stability in long-term production and minimal adverse impact on the environment (Sá et al. 2017). In this context, the use of microbial

\footnotetext{
*Correspondence: mariangela.hungria@embrapa.br;

biotecnologia.solo@hotmail.com; hungria@pq.cnpq.br

1 Embrapa Soja, C.P. 231, Londrina, Paraná 86001-970, Brazil

Full list of author information is available at the end of the article
}

inoculants plays a key role, and we may say that we are starting a "microgreen revolution."

The nomenclature "plant-growth-promoting bacteria (PGPBs)" has been increasingly used for bacteria able to promote plant growth by a variety of individual or combined mechanisms. By this definition, rhizobia-studied and used in commercial inoculants for more than a century-are also PGPBs. Undoubtedly, besides rhizobia, the most studied and used PGPB is Azospirillum, encompassing bacteria with a remarkable capacity to benefit a range of plant species (Bashan and de-Bashan 2010; Hungria et al. 2010; Hungria 2011; Fukami et al. 2016; Pereg et al. 2016).

The genus Spirillum was first reported by Beijerinck (1925), and decades later reclassified as Azospirillum, because of its ability to fix atmospheric nitrogen $\left(\mathrm{N}_{2}\right)$, discovered and reported by the group of Dr. Johanna Döbereiner in Brazil, in the 1970s (Tarrand et al. 1978). After the discovery that Azospirillum was diazotrophic, 
several studies evaluated its capacity to fix $\mathrm{N}_{2}$ and to replace $\mathrm{N}$-fertilizers when associated with grasses (Okon et al. 1983), including sugarcane (Saccharum spp.), grain crops such as maize (Zea mays L.), wheat (Triticum aestivum L.), and rice (Oryza sativa L.), pastures such as Brachiaria (=Uruchloa), among others (Lima et al. 1987; Cassán et al. 2015; Marks et al. 2015; Fukami et al. 2016; Hungria et al. 2016; Pereg et al. 2016). Twenty species of Azospirillum (DSMZ 2018) have been described so far, but $A$. brasilense and $A$. lipoferum have been the subjects of the highest numbers of physiological and genetic studies (Baldani and Baldani 2005; Fibach-Paldi et al. 2012).

Beneficial results have been obtained consistently with Azospirillum applied to a variety of crops (e.g. Okon and Labandera-Gonzalez 1994; Bashan et al. 2004; Pereg et al. 2016) in dozens of commercial inoculants worldwide (Okon et al. 2015). Intriguingly, although the Brazilian research group headed by Dr. Döbereiner contributed to dozens of studies with Azospirillum (Döbereiner and Pedrosa 1987; Reis et al. 2000; Baldani and Baldani 2005), it was only in 2009 that the first commercial inoculant containing A. brasilense started to be commercialized in the country (Hungria et al. 2010; Hungria 2011); however, more than 3 million doses of inoculants are now applied annually by farmers, for inoculation both of non-legumes and for co-inoculation of legumes.

Although the most prevalent reported benefit of Azospirillum has been its capacity of fixing $\mathrm{N}_{2}$, an increasing number of studies describes other properties that imply growth-promotion. One main property of Azospirillum relies on the synthesis of phytohormones and other compounds, including auxins (Spaepen and Vanderleyden 2015), cytokinins (Tien et al. 1979), gibberellins (Bottini et al. 1989), abscisic acid (Cohen et al. 2008), ethylene (Strzelczyk et al. 1994), and salicylic acid (Sahoo et al. 2014). Phytohormones greatly affect root growth, resulting in improvements in uptake of moisture and nutrients (Ardakani and Mafakheri 2011). Some Azospirillum strains can solubilize inorganic phosphorus, making it more readily available to the plants and resulting in higher yields (Turan et al. 2012). There are also reports of Azospirillum helping in the mitigation of abiotic stresses, such as salinity and drought (Creus et al. 2004; Rodríguez-Salazar et al. 2009; Kim et al. 2012), by triggering induced systemic tolerance (IST) (Yang et al. 2009). Azospirillum has also been reported to help in the mitigation of excessive compost and heavy metals (Bacilio et al. 2003; de-Bashan et al. 2010). Another important feature of Azospirillum is related to biological control of plant pathogens (Bashan and de-Bashan 2002a, b; Khan et al. 2002; Romero et al. 2003; Tortora et al. 2011), enabled by the synthesis of siderophores, and limiting the availability of iron (Fe) to phytopathogens (Tortora et al.
2011), or causing alterations in the metabolism of the host plant, including the synthesis of a variety of secondary metabolites that increase plant resistance to infection by pathogens, a mechanism known as induction of systemic resistance (ISR) (Sudha and Ravishankar 2002; van Loon and Bakker 2005). Due to the several mechanisms reported to promote plant growth, Bashan and De-Bashan (2010) proposed the "theory of multiple mechanisms" in which the bacterium acts in a cumulative or sequential pattern of effects, resulting from mechanisms occurring simultaneously or consecutively. In this review we will give emphasis to the mechanisms of $A z o s$ pirillum that can improve plant tolerance of biotic and abiotic stresses (Fig. 1).

\section{Oxidative stress}

Abiotic and biotic stresses result in oxidative damage to plants due to an increase in reactive oxygen species (ROS), representing an initial mechanism of plant response to the attack of pathogens (Finkel 2000; León and Montesano 2013), and of defense against abiotic stresses (Heidari and Golpayegani 2012; Wang et al. 2012).

The ROS molecules encompass free radicals resulting from the oxygen $\left(\mathrm{O}_{2}\right)$ metabolism, including superoxide radicals $\left(\mathrm{O}_{2}^{-}\right)$, hydroxyl radicals $\left(\mathrm{OH}^{-}\right)$, hydrogen peroxide $\left(\mathrm{H}_{2} \mathrm{O}_{2}\right)$, and singlet oxygen $\left({ }^{1} \mathrm{O}_{2}\right)$ (Bowler et al. 1992; Gill and Tuteja 2010). Under normal conditions, ROS are produced via the aerobic metabolism by the interaction between $\mathrm{O}_{2}$ and electrons escaping from the electron transport chain in the chloroplast and mitochondria (Halilwell and Gutteridge 1989). However, under stress conditions, ROS accumulation affects cellular components, causing damage to membranes by lipid peroxidation (Smirnoff 1993), and/or by the accumulation of solutes, such as proline and betaine, which may protect cells against increased levels of ROS (Chen and Murata 2002).

Oxidative stress is relieved in plants by antioxidant enzymes, such as superoxide dismutase (EC 1.15.1.1; SOD), catalase (EC 1.11.1.6; CAT), and ascorbate peroxidase (EC 1.11.1.11; APX) (Wisniewski-Dyé et al. 2012; Ozyigit et al. 2016). The enzyme SOD is the first in the defense against ROS, converting the radical superoxide $\left(\mathrm{O}_{2}{ }^{-}\right)$to $\mathrm{H}_{2} \mathrm{O}_{2}$, which is then removed by CAT and APX by the conversion of $\mathrm{H}_{2} \mathrm{O}_{2}$ to water $\left(\mathrm{H}_{2} \mathrm{O}\right)$ and $\left(\mathrm{O}_{2}\right)$ (Lamb and Dixon 1997; Asada 1999). In general, ROS detoxification systems vary with plant species, genotypes, and age, as well as with the type and duration of stress (Hodges et al. 1996).

The genes that encode the detoxification enzymes are found in different compartments of plant cells, varying in number and location, depending on the plant species. 


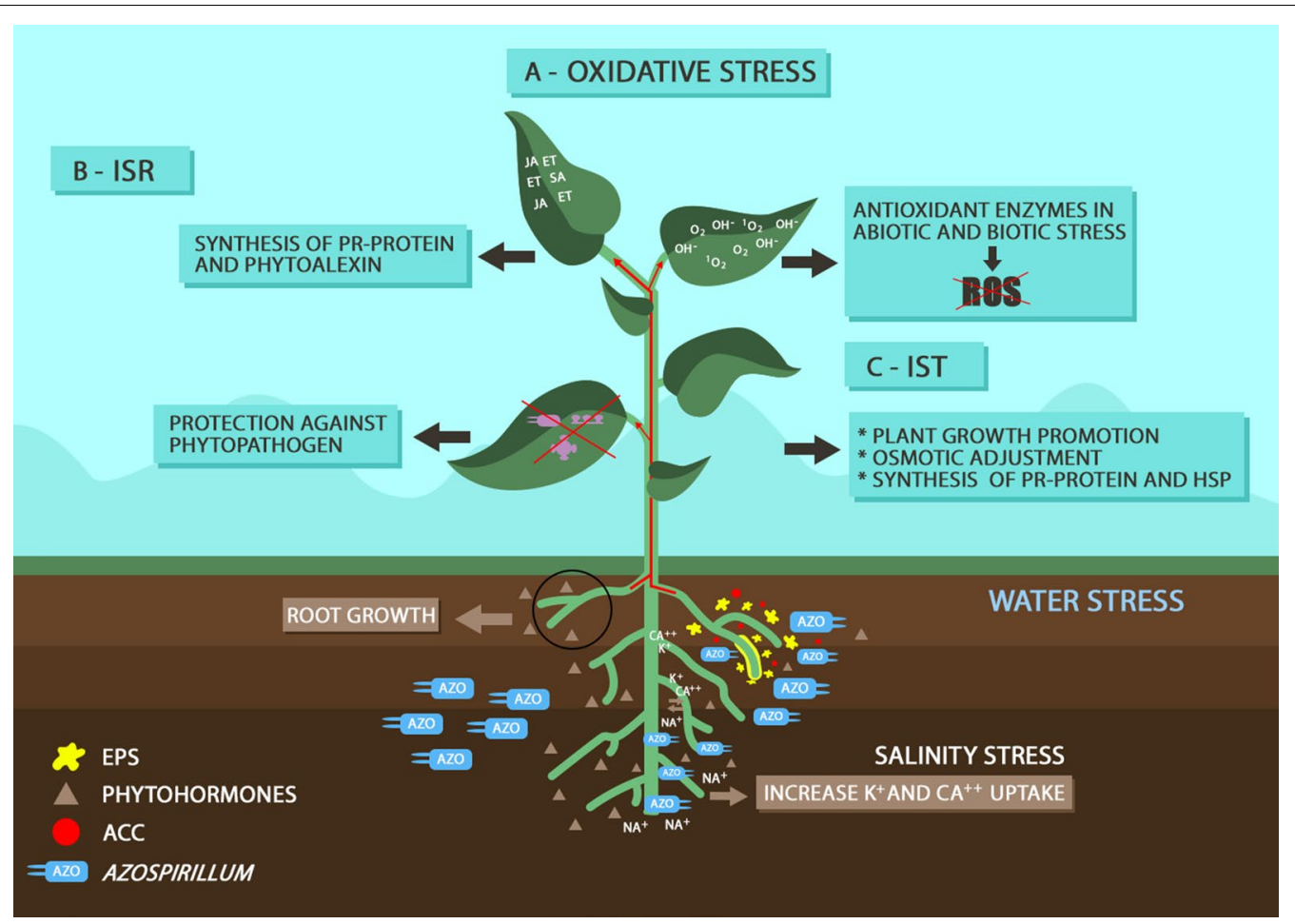

Fig. 1 Mechanisms of tolerance of biotic and abiotic stresses induced by Azospirillum in plants. Tolerance to biotic stress include induced systemic resistance (ISR), mediated by increased levels of phytohormones in the jasmonic acid (JA)/ethylene (ET) pathway independent of salicylic acid (SA), and systemic acquired resistance (SAR) — a mechanism previously studied with phytopathogens — controlled by intermediate levels of SA. Tolerance of abiotic stresses, named as induced systemic tolerance (IST), is mediated by antioxidants, osmotic adjustment, production of phytohormones, and defense strategies such as the expression of pathogenesis-related $(P R)$ genes

SOD enzymes are divided into three groups, based on the cofactor metal: the copper/zinc $(\mathrm{Cu} / \mathrm{ZnSOD})$, iron (FeSOD), and manganese (MnSOD) classes (Jozefczak et al. 2015). The SOD system in maize consists of several isoenzymes; SOD2, SOD4, SOD4A, and SOD5 are found in the cytosol $(\mathrm{Cu} / \mathrm{ZnSOD})$, while SOD3 (MnSOD) is encoded by the $\operatorname{sod} 3$ multigene family and located in the mitochondria (Jung et al. 2001).

APX isoenzymes in superior plants are encoded by a multigenic family (Ozyigit et al. 2016); the APX1 and APX2 cytosolic isoforms are the most important in the APX family in providing antioxidant protection (Shigeoka and Maruta 2014), induced mainly under extreme light conditions or heat stress (Davletova et al. 2005). In relation to the CAT isoenzymes, CAT1 and CAT2 are found in peroxisomes, glyoxysomes, and also in the cytosol (Scandalios et al. 1997), and CAT3 in the mitochondria (Jung et al. 2001).

Although early studies have focused on plant response to phytopathogens, there are indications that PGPBs may induce plant oxidative stress as an initial defense response, probably because plants perceive these microorganisms as potential threats. What is now known is that PGPB, including Azospirillum, are capable of inducing the synthesis of antioxidant enzymes in plants, reducing the deleterious effects of ROS (Han and Lee 2005; Heidari and Golpayegani 2012; Upadhyay et al. 2012; Fukami et al. 2017, 2018).

Although Azospirillum appears to lack host specificity in the promotion of plant growth (Pereg et al. 2016), there are also indications that strains may vary in determinants that will contribute to the adaptation to the rhizospheric niche, affecting plant-bacterial interactions (Wisniewski-Dyé et al. 2012). Therefore, mechanisms of oxidative stress may contribute to the success of plant colonization. For example, Drogue and collaborators (2014) reported that colonization of A. lipoferum strain $4 \mathrm{~B}$ in the rice rhizosphere seems to involve genes related to the detoxification of ROS, and similar results were reported for A. brasilense strain Sp245 in Arabidopsis thaliana (Spaepen et al. 2014), wheat (Méndez-Gómez et al. 2015), and also for A. brasilense strains Ab-V5 and Ab-V6 in maize (Fukami et al. 2017, 2018). 


\section{Plant defense mechanisms to biotic stresses Induced systemic resistance}

Plants have several inducible mechanisms against pathogens attack. A classic example is the acquired systemic resistance (SAR), which is activated after infection by a necrotrophic pathogen, and confers resistance to plants against a broad spectrum of pathogens, as well as against secondary infections for weeks or months (Fu and Dong 2013).

Some PGPB also show the capacity of inducing plant defense mechanisms, conferring resistance to pathogenic bacteria, viruses, and fungi, termed ISR (induced systemic resistance) (Lugtenberg and Kamilova 2009). The ISR triggered by non-pathogenic microorganisms begins in the infected primary tissues and is systemically spread throughout the plant, increasing the defensive capacity of distant tissues against infection of pathogenic agents (van Loon and Bakker 2005; Dutta et al. 2008). Once induced, plants can remain protected for prolonged periods (van Loon 2007). This mechanism was first described by van Peer et al. (1991) in carnation (Dianthus caryophyllus L.), with protection against Fusarium oxysporum f. sp. dianthi via the synthesis and accumulation of phytoalexins resulting from inoculation with Pseudomonas sp. WCS417r. The mechanism was also described by Wei et al. (1991) in cucumber (Cucumis sativus L.), in which six out of the 94 strains of PGPB evaluated, encompassing five species of Pseudomonas and one of Serratia, protected the leaves against anthracnose caused by Colletotrichum orbiculare.

van Loon (2007) defined four main mechanisms by which PGPB may induce ISR in plants: (i) developmental, escape: related to plant-growth promotion; (ii) physiological, tolerance: reduction of symptom expression; (iii) environmental: associated with microbial antagonism in the rhizosphere; (iv) biochemical resistance: by induction of cell-wall reinforcement, of phytoalexins synthesis, of pathogenesis-related (PR) proteins, and "priming" of defense responses (resistance), enabling the plants to rapidly and effectively activate cellular defense responses that are induced by contact with the pathogen.

The ISR is also characterized by specific plant-PGPB interactions, implying that a PGPB that is capable of triggering ISR in a particular plant species may not be effective in another (van Loon 2007). The main group of PGPB that triggers ISR includes strains of the genera Azospirillum, Pseudomonas and Bacillus (Pérez-Montaño et al. 2014). A transcriptomic study of Azospirillum sp. strain B510 (isolated from cultivar Nipponbare) inoculated in rice induced one and repressed five $P R$-genes, whereas A. lipoferum strain 4B (isolated from cultivar Cigalon) induced more defense-related genes in Nipponbare than in Cigalon (Drogue et al. 2014). In another study with $A$. thaliana, $P R$-genes were induced when the plant was inoculated with $A$. brasilense strain Sp245 (Spaepen et al. 2014). $P R$-genes were also induced in maize inoculated with A. brasilense strains Ab-V5 and Ab-V6 (Fukami et al. 2017, 2018).

The SAR is associated with the synthesis and accumulation of salicylic acid (SA) in the plant, activating a coordinated expression of genes that encode PR-proteins (Kawagoe et al. 2015). One study demonstrated that NPR1 ("nonexpressor of PR-gene1", related to the plant's defense system) is an essential regulator in the SAR mechanism; it is transported to the cell nucleus in response to SA, where it acts as a transcriptional coactivator of a set of $P R$-genes (Pajerowska-Mukhtar et al. 2013; Pieterse et al. 2012, 2014), with an emphasis on $P R$ 1, PR-2, and PR-5 (Malamy et al. 1990; Uknes et al. 1992). The PR-proteins have different functions, some still unknown. We may cite as an example $P R-1$ (a member of a multigene family) (Morris et al. 1998) with unknown biochemical function (van Loon et al. 2006), and PR-2, related to the synthesis of a $\beta$-1-3-glucanase (Kauffmann et al. 1987), which inhibits pathogenic fungal growth, since the main structural components of the cell wall of these microorganisms are chitin and $\beta$-glucan.

The activation/repression of $P R$-genes, mediated by NPR1, is tightly related to the levels of SA in plants. NPR1 assists in the activation of programmed cell death, acting as a negative regulator (Caarls et al. 2015). When the levels of SA are low, NPR4 (a paralog of NPR1) interacts with NPR1, leading to its degradation. Likewise, when the levels of SA are high, the binding between NPR1 and NPR3 (a paralog of NPR1) is promoted, and also results in the removal of NPR1 (Fu et al. 2012). When the SA level is intermediate, the interaction between NPR1 and NPR3 is suppressed, leading to the accumulation of NPR1, and activating the SA-dependent defense genes (Caarls et al. 2015).

In the case of ISR, studies on different species of PGPB and plants have established that the nature of the induced resistance, in most cases, is independent of SA (Yan et al. 2002; De Vleesschauwer et al. 2008; Segarra et al. 2009) and, in general, is associated with signaling molecules, such as jasmonic acid (JA) and its derivatives (such as jasmonate), and ethylene (ET) (Glick 2012; Ahemad and Kibret 2014), involving the induction of PR-proteins, such as PR-3 and PR-4 (chitinase family), and PDF1.2 (a plant defensin) (van Loon and van Strien 1999; Gond et al. 2015). In a study with strawberry (Fragaria ananassa) inoculated with A. brasilense REC3, Elias et al. (2018) reported increased ET synthesis and up-regulation 
of genes associated with ET signaling (Faetr1, Faers1, Faein4, Factr1, Faein2 and Faaco1), supporting the hypothesis of priming activation characteristic of ISR mediated by this PGPB.

There is evidence that the mechanisms of ISR, with signaling by JA/ET, are different from SAR, mediated by NPR1 (Spoel 2003; Stein et al. 2008; Pieterse et al. 2012; Pieterse and Van Wees 2015). The evidence corroborates the results of Yasuda et al. (2009), in which rice plants inoculated with Azospirillum sp. B510 increased the plant resistance to the pathogenic fungus Magnoporthe oryzae and to the bacterium Xanthomonas oryzae, through mechanisms independent of SA-signaling, with no accumulation of SA or PR-proteins. Similar results were described by De Vleesschauwer and collaborators (2008) for P. fluorescens WCS374r. However, other studies using cells and metabolites of $A$. brasilense Ab-V5 and Ab-V6 applied by different methods resulted in the induction of $P R-1$ SAR-related and PRP-4 ISR-related genes (Fukami et al. 2017).

Several studies have demonstrated that the exogenous applications of SA (Bari and Jones 2009) and JA (Lorenzo and Solano 2005; Wasternack 2007; Bari and Jones 2009) in plants induce $P R$-genes, resulting in increased resistance to various phytopathogens. Agrawal and collaborators (2000) reported the first evidence of exogenous application of JA as an effective inducer of the PR1 family in rice. There are also reports of the application of ISRinducing chemicals, such as JA or SA, in reducing the incidence of diseases in rice. However, the application of purified exopolysaccharides (EPS) of Azospirillum also conferred resistance against the fungus Pyricularia oryzae (Sankari et al. 2011), suggesting that EPS may represent another alternative for increasing ISR.

\section{Plant defense mechanisms to abiotic stresses}

Plants are commonly exposed to several environmental stresses such as high and low temperatures, drought, salinity, alkalinity, UV-rays (Sharma et al. 2012); estimates are that about $30 \%$ of the global crop production is lost as a result of abiotic stresses (Goswami et al. 2016), and PGPB can play a strategic role in reducing these losses, by activating several physiological and biochemical tolerance mechanisms in plants (Yang et al. 2009; Kim et al. 2012; Sarma et al. 2012), named induced systemic tolerance (IST). The mechanisms related to IST include antioxidant defense (Heidari and Golpayegani 2012; Wang et al. 2012), osmotic adjustment (Sarma and Saikia 2014), production of phytohormones such as indole-3-aceticacid (IAA) (Spaepen and Vanderleyden 2015), defense strategies such as the expression of $P R$-genes (Kim et al. 2014), and the induction of heat-shock proteins (HSP) (Lim and Kim 2013).

\section{Saline stress}

Salinity is considered one of the most critical abiotic stresses, impacting agricultural productivity and sustainability due to reductions in photosynthesis, respiration, and protein synthesis (Ahmad and Prasad 2012; Dwivedi et al. 2015). Salinity also causes nutritional disturbances in plants that lead to the deficiency of various nutrients and the increase in sodium $\left(\mathrm{Na}^{+}\right)$levels (Zahedi et al. 2012). First, the high concentration of salt in the rhizosphere affects water absorption by the plants; subsequently, toxic ionic concentrations inside the plants result in inhibition of many physiological and biochemical processes, such as the absorption and assimilation of nutrients (Hasegawa et al. 2000; Munns and Tester 2008).

Plants use many important adaptive mechanisms to deal with the adverse effects of salinity, one of them being the accumulation of solutes, including amino acids (proline), sugars (mannitol), and quaternary ammonium (glycine betaine), which help to maintain the water within the cells, combating dehydration (Nuccio et al. 1999). Another mechanism is the increase in ROS synthesis in cells (Gururani et al. 2013), as well as of the cytosolic expression of APX (Torsethaugen et al. 1997).

Among the PGPB, the genus Azospirillum-with an emphasis on $A$. brasilense-is probably the most studied microorganism for the mitigation of salinity stress in various cultures (Creus et al. 2004; Barassi et al. 2006; Rodríguez-Salazar et al. 2009; Carrozzi et al. 2012; Fasciglione et al. 2015). Example of effects of Azospirillum include the study by Hamdia and collaborators (2004), that reported that the inoculation of Azospirillum spp. in cultivars of maize altered the selectivity of $\mathrm{Na}^{+}, \mathrm{K}^{+}$, and $\mathrm{Ca}^{++}$ions, by restricting $\mathrm{Na}^{+}$absorption and increasing $\mathrm{K}^{+}$and $\mathrm{Ca}^{++}$uptake; the protective role of the bacterium was verified by the reduction in proline content, and also by plant-growth promotion. Likewise, plant-growth promotion and lower accumulation of solutes were also reported by Fukami et al. (2017) in maize inoculated with A. brasilense $\mathrm{Ab}-\mathrm{V} 6$, but not with $\mathrm{Ab}-\mathrm{V} 5$, indicating differences between strains. In addition, Fukami et al. (2017) observed that inoculation with strain Ab-V6 induced the expression of genes related to antioxidant enzymes, and similar results were reported when different species of Azospirillum were used in inoculants applied to canola (Brassica napus L.) (Baniaghil et al. 2013).

In another study, inoculation with $A$. brasilense strain $\mathrm{NH}$, but not with Sp7 (Nabti et al. 2009), was very effective in restoring the vegetative growth and seed yield of durum wheat (Triticum durum var. Waha) grown with 160 and $200 \mathrm{mM} \mathrm{NaCl}$, reducing the accumulation of proline and total sugars (Alamri and Mostafa 2009). Other studies reported beneficial effects of inoculation of $A$. brasilense on sweet pepper (Capsicum annuum L.) 
(Amor and Cuadra-Crespo 2012), and white clover (Trifolium repens) (Khalid et al. 2017).

It is worth mentioning that several rhizobial strains can also help to increase plant tolerance of salinity, as has been reported for pea (Pisum sativum L.), fava beans (Vicia faba L.) (del Cordovilla et al. 1999), common bean (Phaseolus vulgaris L.) (Dardanelli et al. 2008; Fukami et al. 2018), and also in non-legumes as lettuce (Lactuca sativa L.) (Han and Lee 2005). This may be due, at least partially, to the ability of some rhizobial strains to synthesize phytohormones (Yanni and Dazzo 2015; Imada et al. 2017), increasing root growth, a property that is expanding their use as PGPB also in non-legumes (Askary et al. 2009; García-Fraile et al. 2012; Hasan et al. 2014; Yanni and Dazzo 2015).

\section{Drought stress}

Drought is another major limitation to crop production worldwide (Lesk et al. 2016), and global climate changes are increasing the frequency of negative reports. Many mathematical models predict reductions in rainfall and increases in temperatures by 2050 (IPCC 2014; Shanker et al. 2014), resulting in agricultural losses for economically important crops, and impacting food security (Foley et al. 2011; IPCC 2014). Thus, there is need to increase drought tolerance in crops and increase yields under conditions of depleted moisture availability (Ngumbi and Kloepper 2016).

Moisture shortage in plants affects stomatal function, which reduces the leaf $\mathrm{CO}_{2} / \mathrm{O}_{2}$ ratio, inhibiting photosynthesis with concomitant reduction of biomass production (Gilbert et al. 2011; Lopes et al. 2011; Mutava et al. 2015). Under severe conditions, drought induces oxidative stress in plants, resulting from the accumulation of ROS (Souza et al. 2013; Silva et al. 2014). The plant responds with the synthesis and activity of several antioxidant enzymes, such as CAT, peroxides (POX), SOD, glutathione peroxidase (GPX), and APX (SimovaStoilova et al. 2008). In addition, other strategies such as osmotic adjustment, maintenance of root viability, membrane stability, and accumulation of proteins and other metabolites-including proline, glycine betaine, and trehalose-help, directly or indirectly, in the maintenance of plant metabolism under drought stress (Huang et al. 2014; Cohen et al. 2015; Ngumbi and Kloepper 2016).

Inoculation with PGPB may be strategic to increase drought tolerance (Marulanda et al. 2007), since these microorganisms can elicit IST (Yang et al. 2009). In addition, PGPB may help plant-drought tolerance by the production of EPS (Sandhya et al. 2010), phytohormones (Dodd et al. 2010; Fibach-Paldi et al. 2012), 1-aminocyclopropane-1-carboxylate (ACC) deaminase (Lim and Kim 2013), volatile compounds, inducing the accumulation of osmolytes (Cohen et al. 2015), antioxidants, up- or down-regulation of stress-responsive genes (Ngumbi and Kloepper 2016; Vurukonda et al. 2016), and changes in root morphology (Rodríguez-Salazar et al. 2009; Cohen et al. 2015).

In a pioneer study of the effects of PGPB in plant-gene expression, Timmusk and Wagner (1999) reported that the inoculation of $A$. thaliana with Paenibacillus polymyxa induced the drought-responsive gene ERD15 (early response to dehydration). In another study, inoculation with Pseudomonas spp. compensated the drought effects with an enhanced synthesis of proline, amino acids, and soluble sugars, which resulted in better absorption of moisture and nutrients and enhanced plant growth (Sandhya et al. 2010). Furthermore, Pseudomonas strains produced abundant EPS under stress, providing a microenvironment that favored water maintenance, and protected both the microorganism and the plant against dehydration (Alami et al. 2000; Sandhya et al. 2010).

In various studies, the role of Azospirillum in mediating drought tolerance has been documented (Bano et al. 2013; Cohen et al. 2015; Hungria et al. 2015; Saeed et al. 2016; Curá et al. 2017). Noteworthy, drought tolerance of Azospirillum was reported even in drastic conditions of deserts (Bashan et al. 2012). Positive effects have been attributed to the synthesis of abscisic acid (ABA), inducing stomatal closure (Cohen et al. 2015), as well as to the accumulation of solutes such as free amino acids and soluble sugars, which help mitigate dehydration. Azospirillum also improves plant traits that can help tolerance of water deficit, such as root branching, increased root biomass, increased density of root hairs (Cassán and García de Salamone 2008; Lopes et al. 2011; Hungria et al. 2015), which foster exploration of the water in the soil; improvements in plant-root activity have been explained in terms of the action of phytohormones synthesized by PGPB, such as IAA (Saharan and Nehra 2011).

In a study performed by Saeed and collaborators (2016), when canola seeds were inoculated with A. lipoferum, there were increases in percentage germination, in rootsurface area and in chlorophyll content, and improvement in water potential under drought conditions. In another study, A. brasilense increased Arabidopsis growth, proline levels, photosynthetic and photoprotective pigments, and decreased stomatal conductance and water losses under drought, attributes that were correlated with increases in ABA levels (Cohen et al. 2015). More recently, Curá et al. (2017) demonstrated that inoculation of maize with A. brasilense or Herbaspirillum seropedicae improved plant tolerance to desiccation, effects correlated with ABA and ethylene contents. Therefore, the use of PGPB strains-especially Azospirillum-is promising for the mitigation of drought effects 
on crop plants. However, it is important to consider that strains of Azospirillum may differ in their properties the confer tolerance of drought, justifying a selection of the most effective ones (García et al. 2017).

Remarkably, inoculation with Azospirillum, a typical rhizospheric bacterium, via foliar spray can also increase plant growth (Fukami et al. 2016), attributable to the synthesis of IAA by the bacterium, i.e. a plant-signaling process mediated by the bacterium, far stronger than when synthetic IAA was applied (Puente et al. 2017). Intriguingly, in maize, foliar application of Azospirillum also elicited genes related to tolerance of abiotic stresses (APX1, APX2, SOD4), as well as defense genes (PR-genes), which has also been attributed to phytohormones signaling (Fukami et al. 2017). Also in brachiaria (U. ruziziensis), foliar application of Azospirillum Ab-V5 and $\mathrm{Ab}-\mathrm{V} 6$ increased the tolerance of water stress, by increasing the activity of enzymes related to the removal of reactive oxygen species, protecting chlorophyll a (Bulegon et al. 2016).

We may also consider that different microorganisms and microbial processes can be combined to make agriculture more sustainable and productive, helping to mitigate the impacts of abiotic stresses. One important example relies on the co-inoculation of rhizobial and non-rhizobial PGPB, with several reports of increased yields, for example, with soybean (Hungria et al. 2013; Pérez-Montaño et al. 2014; Chibeba et al. 2015; Cerezini et al. 2016; Puente et al. 2017), and common bean (Phaseolus vulgaris L.) (Hungria et al. 2013). In the co-inoculation with rhizobia, Azospirillum usually contributes with root-growth promotion (Cassán et al. 2009; Juge et al. 2012), allowing precocity and increased nodulation by the rhizobia (Chibeba et al. 2015). Most importantly, Cerezini et al. (2016) have shown that soybean co-inoculation with Azospirillum and Bradyrhizobium increased grain yield under moderate water restriction (Cerezini et al. 2016), representing a promising technology for the mitigation of abiotic stresses.

\section{Final remarks}

Azospirillum is currently one of the most broadly studied and commercially employed PGPB. Previous studies with Azospirillum emphasize its capacity of fixing atmospheric $\mathrm{N}_{2}$, followed by benefits in promoting plant growth via synthesis of phytohormones. More recently, it has been shown that the benefits should be extended to the capacity of some Azospirillum strains to protect plants from biotic stresses, triggering ISR defense mechanisms, and from abiotic stresses, through IST. Figure 1 summarizes the mechanisms discussed in this review of tolerance of abiotic and biotic stresses promoted by inoculation of Azospirillum in plants, encompassing detoxification of oxidative stress, ISR and IST. The mechanisms that PGPB use to cope with biotic and abiotic stresses vary with the plant species and cultivar and with the bacterial species and strains, and also depend on the phytopathogen and the intensity of the abiotic stress. Further studies to elucidate the mechanisms of action of PGPB-as well as of the response of plants to stresses-are of fundamental importance for understanding the potential and increasing the use of PGPB as an important and sustainable strategy to mitigate the effects of biotic and abiotic stresses in agriculture.

\section{Authors' contributions}

JF, PC and MH participated in all stages of writing the manuscript. All authors read and approved the final manuscript.

\section{Author details}

${ }^{1}$ Embrapa Soja, C.P. 231, Londrina, Paraná 86001-970, Brazil. ${ }^{2}$ Department Biochemistry and Biotechnology, Universidade Estadual de Londrina, C.P. 60001 , Londrina, Paraná 86051-990, Brazil.

\section{Acknowledgements}

Research group supported by the INCT-Plant-Growth Promoting Microorganisms for Agricultural Sustainability and Environmental Responsibility (CNPq 465133/2014-2, Fundação Araucária-STI, CAPES), and CNPq-Universal (400468/2016-6). J. Fukami acknowledges a Ph.D. fellowship from CAPES, P. Cerezini a post-doc fellowship from CNPq; M. Hungria is also a fellow from CNPq. Authors thank Dr. Allan R. J. Eaglesham for English review.

\section{Competing interests}

The authors declare that they have no competing interests.

Availability of data and materials

All data and materials cited on the manuscript are freely available for the scientific community.

\section{Consent for publication}

All authors gave the consent for publication.

Ethics approval and consent of participation

The study has not involved any human or animal participation or data.

Ethical interests

Authors declare no ethical problems.

Funding information

Financed by INCT-Plant-Growth Promoting Microorganisms for Agricultural Sustainability and Environmental Responsibility (CNPq 465133/2014-2, Fundação Araucária-STI, CAPES); CNPq-Universal (400468/2016-6); CAPES (Ph.D. fellowship).

\section{Publisher's Note}

Springer Nature remains neutral with regard to jurisdictional claims in published maps and institutional affiliations.

Received: 3 April 2018 Accepted: 30 April 2018

Published online: 04 May 2018

\footnotetext{
References

Agrawal GK, Jwa NS, Rakwal R (2000) A novel rice (Oryza sativa L.) acidic PR1 gene highly responsive to cut, phytohormones, and protein phosphatase inhibitors. Biochem Biophys Res Commun 274:157-165. https://doi.org/10.1006/bbrc.2000.3114
} 
Ahemad M, Kibret M (2014) Mechanisms and applications of plant growth promoting rhizobacteria: current perspective. JKSUS 26:1-20. https:// doi.org/10.1016/j.jksus.2013.05.00

Ahmad P, Prasad MNV (2012) Environmental adaptations and stress tolerance of plants in the era of climate change. Springer Science \& Business Media, Berlin. ISBN 978-1-4614-0815-4

Alami Y, AchouakW, Marol C, Heulin T (2000) Rhizosphere soil aggregation and plant growth promotion of sunflowers by an exopolysaccharideproducing Rhizobium sp. Strain isolated from sunflower roots. Appl Environ Microbiol 66:3393-3398. https://doi.org/10.1128/ AEM.66.8.3393-3398.2000

Alamri SA, Mostafa YS (2009) Effect of nitrogen supply and Azospirillum brasilense Sp-248 on the response of wheat to seawater irrigation. Saudi J Biol Sci 16:101-107. https://doi.org/10.1016/j.sjbs.2009.10.009

Amor FM, Cuadra-Crespo P (2012) Plant growth-promoting bacteria as a tool to improve salinity tolerance in sweet pepper. Funct Plant Biol 39:82-90. https://doi.org/10.1071/FP11173

Ardakani M, Mafakheri S (2011) Designing a sustainable agroecosystem for wheat (Triticum aestivum L.) production. J Appl Environ Biol Sci 1:401-413. https://doi.org/10.1016/S1573-5214(07)80001-7

Asada K (1999) The water-water cycle in chloroplasts: scavenging of active oxygens and dissipation of excess photons. Annu Rev Plant Physiol Plant Mol Biol 50:601-639. https://doi.org/10.1146/annurev.arplant.50.1.601

Askary M, Mostajeran A, Amooaghaei R, Mostajeran M (2009) Influence of the co-inoculation Azospirillum brasilense and Rhizobium meliloti plus 2,4-D on grain yield and N, P, K content of Triticum aestivum (CV. Baccros and Mahdavi). Am J Agric Environ Sci. 5:296-307. ISSN 1818-6769

Bacilio M, Vazquez P, Bashan Y (2003) Alleviation of noxious effects of cattle ranch composts on wheat seed germination by inoculation with Azospirillum spp. Biol Fertil Soils 38:261-266. https://doi.org/10.1007/ s00374-003-0650-1

Baldani Jl, Baldani VLD (2005) History on the biological nitrogen fixation research in graminaceous plants: special emphasis on the Brazilian experience. An Acad Bras Ciênc 77:549-579. https://doi.org/10.1590/ S0001-37652005000300014

Baniaghil N, Arzanesh MH, Ghorbanli M, Shahbazi M (2013) The effect of plant growth promoting rhizobacteria on growth parameters, antioxidant enzymes and microelements of canola under salt stress. J Appl Environ Biol Sci 3:17-27. ISSN 2090-4274

Bano Q, llyas N, Bano A, Zafar N, Akram A, Hassan F (2013) Effect of Azospirillum inoculation on maize (Zea mays L.) under drought stress. Pakistan J Bot 45:13-20

Barassi CA, Ayrault G, Creus CM, Sueldo RJ, Sobrero MT (2006) Seed inoculation with Azospirillum mitigates $\mathrm{NaCl}$ effects on lettuce. Sci Hortic 109:8-14. https://doi.org/10.1016/j.scienta.2006.02.025

Bari R, Jones JDG (2009) Role of plant hormones in plant defence responses. Plant Mol Biol 69:473-488. https://doi.org/10.1007/s11103-008-9435-0

Bashan Y, de-Bashan LE (2002a) Protection of tomato seedlings against infection by Pseudomonas syringae pv tomato using the plant growthpromoting bacterium Azospirillum brasilense. Appl Environ Microbiol 68:2637-2643. https://doi.org/10.1128/AEM.68.6.2637-2643.2002

Bashan Y, de-Bashan LE (2002b) Reduction of bacterial speck (Pseudomonas syringae pv tomato) of tomato by combined treatments of plant growth-promoting bacterium, Azospirillum brasilense, streptomycin sulfate, and chemothermal seed treatment. Eur J Plant Pathol 108:821 829. https://doi.org/10.1023/A:1021274419518

Bashan Y, Holguin G, de-Bashan LE (2004) Azospirillum-plant relationships: physiological, molecular, agricultural, and environmental advances (1997-2003). Can J Microbiol 50:52-577. https://doi.org/10.1139/ w04-035

Bashan Y, de-Bashan LE (2010) How the plant growth-promoting bacterium Azospirillum promotes plant growth — a critical assessment. Adv Agron 108:77-136. https://doi.org/10.1016/S0065-2113(10)08002-8

Bashan Y, Salazar BG, Moreno M, Lopez BR, Linderman RG (2012) Restoration of eroded soil in the Sonoran Desert with native leguminous trees using plant growth-promoting microorganisms and limited amounts of compost and water. J Environ Manag 102:26-36. https://doi.org/10.1016/j. jenvman.2011.12.032

Beijerinck MW (1925) Über ein Spirillum, welches freien Stickstoff binden kann. Zentralbl Bakteriol Parasitenkd Infekt Abt 63:353
Bottini R, Fulchieri M, Pearce D, Pharis RP (1989) Identification of gibberellins $A_{1}, A_{3}$, and iso- $A_{3}$ in cultures of Azospirillum lipoferum. Plant Physiol 90:45-47. https://doi.org/10.1104/pp.90.1.45

Bowler C, Montagu MV, Inzé D (1992) Superoxide dismutase and stress tolerance. Annu Rev Plant Physiol Plant Mol Biol 43:83-116. https://doi. org/10.1146/annurev.pp.43.060192.000503

Bulegon LG, Guimarães VF, Laureth JCU (2016) Azospirillum brasilense affects the antioxidant activity and leaf pigment content of Urochloa ruziziensis under water stress. Pesqui Agropecu Trop 46:343-349. https://doi. org/10.1590/1983-40632016v4641489

Carrozzi LE, Creus CM, Barassi CA, Monterubbianesi G, Di Benedetto A (2012) Reparation of aged lettuce (Lactuca sativa) seeds by osmotic priming and Azospirillum brasilense inoculation. Botany 90:1093-1102. https:// doi.org/10.1139/b2012-087

Caarls L, Pieterse CMJ, Van Wees SCM (2015) How salicylic acid takes transcriptional control over jasmonic acid signaling. Front Plant Sci 6:1-11. https://doi.org/10.3389/fpls.2015.00170

Cassán FD, García de Salamone IE (2008) Azospirillum sp. Cell physiology, plant interactions and agronomic research in Argentina. I International workshop on Azospirillum: cell physiology, plant response and agronomic research in Argentine 2007

Cassán F, Perrig D, Sgroy V, Masciarelli O, Penna C, Luna V (2009) Azospirillum brasilense Az39 and Bradyrhizobium japonicum E109, inoculated singly or in combination, promote seed germination and early seedling growth in corn (Zea mays L.) and soybean (Glycine max L.). Eur J Soil Biol 45:28-35. https://doi.org/10.1016/j.ejsobi.2008.08.005

Cassán FD, Okon Y, Creus CM (2015) Handbook for Azospirillum. Springer, Switzerland. ISBN 978-3-319-06542-7

Cerezini P, Kuwano BH, dos Santos MB, Terassi F, Hungria M, Nogueira MA (2016) Strategies to promote early nodulation in soybean under drought. Field Crop Res 196:160-167. https://doi.org/10.1016/j. fcr.2016.06.017

Chen THH, Murata N (2002) Enhancement of tolerance of abiotic stress by metabolic engineering of betaines and other compatible solutes. Curr Opin Plant Biol 5:250-257. https://doi.org/10.1016/ S1369-5266(02)00255-8

Chibeba AM, Guimarães MDF, Brito OR, Nogueira MA, Araujo RS, Hungria M (2015) Co-inoculation of soybean with Bradyrhizobium and Azospirillum promotes early nodulation. Am J Plant Sci 6:1641-1649. https://doi. org/10.4236/ajps.2015.610164

Cohen AC, Bottini R, Piccoli PN (2008) Azospirillum brasilense Sp. 245 produces $A B A$ in chemically-defined culture medium and increases ABA content in Arabidopsis plants. Plant Growth Regul 54:97-103. https://doi. org/10.1007/s10725-007-9232-9

Cohen AC, Bottini R, Pontin M, Berli FJ, Moreno D, Boccanlandro H, Travaglia CN, Piccoli PN (2015) Azospirillum brasilense ameliorates the response of Arabidopsis thaliana to drought mainly via enhancement of ABA levels. Physiol Plant 153:79-90. https://doi.org/10.1111/ppl.12221

Creus CM, Sueldo RJ, Barassi CA (2004) Water relations and yield in Azospirilum-inoculated wheat exposed to drought in the field. Can J Bot 82:273-281. https://doi.org/10.1139/b03-119

Curá A, Franz DR, Filosofía JE, Balestrasse KB, Burgueño LE (2017) Inoculation with Azospirillum sp. and Herbaspirillum sp. bacteria increases the tolerance of maize to drought stress. Microorganisms 5:41. https://doi. org/10.3390/microorganisms5030041

Dardanelli MS, Fernández de Córdoba FJ, Espuny MR, Carvajal MAR, Díaz MES, Serrando AMG, Okon Y, Megías M (2008) Effect of Azospirillum brasilense coinoculated with Rhizobium on Phaseolus vulgaris flavonoids and Nod factor production under salt stress. Soil Biol Biochem 40:2713-2721. https://doi.org/10.1016/j.soilbio.2008.06.016

Davletova S, Rizhsky L, Liang H, Shengqiang Z, Oliver DJ, Coutu J, Shulaev V, Schlauch K, Mittler R (2005) Cytosolic ascorbate peroxidase 1 is a central component of the reactive oxygen gene network of Arabidopsis. Plant Cell 17:268-281. https://doi.org/10.1105/tpc.104.026971.1

De Vleesschauwer D, Djavaheri M, Bakker PAHM, Hofte M (2008) Pseudomonas fluorescens WCS374r-induced systemic resistance in rice against Magnaporthe oryzae is based on pseudobactin-mediated priming for a salicylic acid-repressible multifaceted defense response. Plant Physiol 148:1996-2012. https://doi.org/10.1104/pp.108.127878

del Cordovilla M, Berrido SI, Ligero F, Lluch C (1999) Rhizobium strain effects on the growth and nitrogen assimilation in Pisum sativum and Vicia faba 
plant growth under salt stress. J Plant Physiol 154:127-131. https://doi. org/10.1016/S0176-1617(99)80328-9

de-Bashan LE, Hernandez J-P, Nelson NK, Bashan Y, Maier R (2010) Growth of quailbush in acidic, metalliferous desert mine tailings: effect of Azospirillum brasilense Sp6 on biomass production and rhizosphere community structure. Microb Ecol 60:915-927. https://doi.org/10.1007/ s00248-010-9713-7

Döbereiner J, Pedrosa FO (1987) Nitrogen-fixing bacteria in non-leguminous crop plants. Science Tech, Springer Verlag, Madison, p 155. ISBN 0910239118

Dodd IC, Zinovkina NY, Safronova VI, Belimov AA (2010) Rhizobacterial mediation of plant hormone status. Ann Appl Biol 157:361-379. https://doi. org/10.1111/j.1744-7348.2010.00439.x

Drogue B, Sanguin H, Chamam A, Mozar M, Llauro C, Panaud O, Prigent-Combaret C, Picault N, Wisniewski-Dyé F (2014) Plant root transcriptome profiling reveals a strain-dependent response during Azospirillumrice cooperation. Front Plant Sci 5:1-14. https://doi.org/10.3389/ fpls.2014.00607

DSMZ (2018) Prokaryotic nomenclature up-to-date. https://www.dsmz.de/ bacterial-diversity/prokaryotic-nomenclature-up-to-date/prokaryoticnomenclature-up-to-date.html. Accessed 25 Apr 2018

Dutta S, Mishra AK, Dileep Kumar BS (2008) Induction of systemic resistance against fusarial wilt in pigeon pea through interaction of plant growth promoting rhizobacteria and rhizobia. Soil Biol Biochem 40:452-461. https://doi.org/10.1016/j.soilbio.2007.09.009

Dwivedi SL, Sahrawat KL, Upadhyaya HD, Mengoni A, Galardini M, Bazzicalupo M, Biondi EG, Hungria M, Kaschuk G, Blair MW, Ortiz R (2015) Advances in host plant and Rhizobium genomics to enhance symbiotic nitrogen fixation in grain legumes. Adv Agron 129:1-116. https://doi. org/10.1016/bs.agron.2014.09.001

Elias JM, Guerrero-Molina MF, Martínez-Zamora MG, Díaz-Ricci JC, Pedraza RO (2018) Role of ethylene and related gene expression in the interaction between strawberry plants and the plant growth-promoting bacterium Azospirillum brasilense. Plant Biol 20:490-496. https://doi.org/10.1111/ plb.12697

FAO (2009) How to feed the world in 2050. Rome: FAO. http://www.fao.org/ fileadmin/templates/wsfs/docs/expert_paper/How_to_Feed_the_ World_in_2050.pdf. Accessed 01 Jan 18

Fasciglione G, Casanovas EM, Quillehauquy V, Yommi AK, Goni MG, Roura SI, Barassi CA (2015) Azospirillum inoculation effects on growth, product quality and storage life of lettuce plants grown under salt stress. Sci Hortic 195:154-162. https://doi.org/10.1016/j.scienta.2015.09.015

Fibach-Paldi S, Burdman S, Okon Y (2012) Key physiological properties contributing to rhizosphere adaptation and plant growth promotion abilities of Azospirillum brasilense. FEMS Microbiol Lett 326:99-108. https://doi. org/10.1111/j.1574-6968.2011.02407.x

Finkel T (2000) Redox-dependent signal transduction. FEBS Lett 476:52-54. https://doi.org/10.1016/S0014-5793(00)01669-0

Foley JA, Ramankutty N, Brauman KA, Cassidy ES, Gerber JS, Johnston M, Mueller ND, O'Connell C, Ray DK, West PC, Balzer C, Bennett EM, Varpenter SR, Hill J, Monfreda C, Polasky S, Rockström J, Sheehan J, Siebert S, Tilman D, Zaks DPM (2011) Solutions for a cultivated planet. Nature 478:337-342. https://doi.org/10.1038/nature10452

Fu ZQ, Yan S, Saleh A, Wang W, Ruble J, Oka N, Mohan R, Spoel SH, Tada Y, Zheng N, Dong X (2012) NPR3 and NPR4 are receptors for the immune signal salicylic acid in plants. Nature 486:228-232. https://doi. org/10.1038/nature11162

Fu ZQ, Dong X (2013) Systemic acquired resistance: turning local infection into global defense. Annu Rev Plant Biol 64:839-863. https://doi. org/10.1146/annurev-arplant-042811-105606

Fukami J, Nogueira MA, Araujo RS, Hungria M (2016) Accessing inoculation methods of maize and wheat with Azospirillum brasilense. AMB Express 6:1. https://doi.org/10.1186/s13568-015-0171-y)

Fukami J, Ollero FJ, Megías M, Hungria M (2017) Phytohormones and induction of plant stress tolerance and defense genes by seed and foliar inoculation with Azospirillum brasilense cells and metabolites promote maize growth. AMB Express 7:153. https://doi.org/10.1186/s13568-017-0453-7

Fukami J, de la Osa C, Ollero FJ, Megías M, Hungria M (2018) Co-inoculation of maize with Azospirillum brasilense and Rhizobium tropici as a strategy to mitigate salinity stress. Funct Plant Biol 45:328-339. https://doi. org/10.1071/FP17167
García JE, Maroniche G, Creus C, Suárez-Rodríguez R, Ramirez-Trujillo JA, Groppa MD (2017) In vitro PGPR properties and osmotic tolerance of different Azospirillum native strains and their effects on growth of maize under drought stress. Microbiol Res 202:21-29. https://doi. org/10.1016/j.micres.2017.04.007

García-Fraile P, Carro L, Robledo M, Ramírez-Bahena MH, Flores-Félix D, Fernández MT, Mateos PF, Rivas R, Igual JM, Martínez-Molina E, Peix A, Velázquez E (2012) Rhizobium promotes non-legumes growth and quality in several production steps: towards a biofertilization of edible raw vegetables healthy for humans. PLoS ONE 7(5):e38122. https://doi. org/10.1371/journal.pone.0038122

Gilbert ME, Zwieniecki MA, Holbrook NM (2011) Independent variation in photosynthetic capacity and stomatal conductance leads to differences in intrinsic water use efficiency in 11 soybean genotypes before and during mild drought. J Exp Bot 62:2875-2887. https://doi.org/10.1093/ jxb/erq461

Gill SS, Tuteja N (2010) Reactive oxygen species and antioxidant machinery in abiotic stress tolerance in crop plants. Plant Physiol Biochem 48:909-930. https://doi.org/10.1016/j.plaphy.2010.08.016

Glick BR (2012) Plant growth-promoting bacteria: mechanisms and applications. Scientifica (Cairo) 2012:1-15. https://doi. org/10.6064/2012/963401

Gond SK, Bergen MS, Torres MS, White JF Jr, Kharwar RN (2015) Effect of bacterial endophyte on expression of defense genes in Indian popcorn against Fusarium moniliforme. Symbiosis 66:133-140. https://doi. org/10.1007/s13199-015-0348-9

Goswami D, Thakker JN, Dhandhukia PC, Tejada Moral M (2016) Portraying mechanics of plant growth promoting rhizobacteria (PGPR): a review. Cogent Food Agric 2:1127500. https://doi.org/10.1080/23311932.2015 .1127500

Gururani MA, Upadhyaya CP, Baskar V, Venkatesh J, Nookaraju A, Park SW (2013) Plant growth-promoting rhizobacteria enhance abiotic stress tolerance in Solanum tuberosum through inducing changes in the expression of ROS-scavenging enzymes and improved photosynthetic performance. J Plant Growth Regul 32:245-258. https://doi.org/10.1007/ s00344-012-9292-6

Halilwell B, Gutteridge JMC (1989) Free radicals in biology and medicine. Clarendon Press, Oxford. https://doi.org/10.1093/acprof: oso/9780198717478.001.0001

Hamdia MAES, Shaddad MAK, Doaa MM (2004) Mechanisms of salt tolerance and interactive effects of Azospirillum brasilense inoculation on maize cultivars grown under salt stress conditions. Plant Growth Regul 44:165-174. https://doi.org/10.1007/s10725-004-3131-0

Han HS, Lee KD (2005) Plant growth promoting rhizobacteria effect on antioxidant status, photosynthesis, mineral uptake and growth of lettuce under soil salinity. Res J Agric Biol Sci 1:210-215

Hasan M, Bano A, Hassan SG, Iqbal J, Awan U, Rong-ji D, Khan KA (2014) Enhancement of rice growth and production of growth-promoting phytohormones by inoculation with Rhizobium and other Rhizobacteria. World Appl Sci J 31:1734-1743. https://doi.org/10.5829/idosi. wasj.2014.31.10.364

Hasegawa PM, Bressan RA, Zhu JK, Bohnert HJ (2000) Plant cellular and molecular responses to high salinity. Annu Rev Plant Physiol Plant Mol Biol 51:463-499. https://doi.org/10.1146/annurev.arplant.51.1.463

Heidari M, Golpayegani A (2012) Effects of water stress and inoculation with plant growth promoting rhizobacteria (PGPR) on antioxidant status and photosynthetic pigments in basil (Ocimum basilicum L.). J Saudi Soc Agric Sci 11:57-61. https://doi.org/10.1016/j.jssas.2011.09.001

Hodges DM, Andrews CJ, Johnson DA, Hamilton RI (1996) Antioxidant compound response to chilling stress in differentially sensitive inbred maize line. Physiol Plant 98:685-692. https://doi.org/10.1093/jxb/48.5.1105

Huang B, DaCosta M, Jiang Y (2014) Research advances in mechanisms of turfgrass tolerance to abiotic stresses: from physiology to molecular biology. CRC Crit Rev Plant Sci 33:141-189. https://doi.org/10.1080/073 52689.2014.870411

Hungria M, Campo RJ, Souza EM, Pedrosa FO (2010) Inoculation with selected strains of Azospirillum brasilense and A. lipoferum improves yields of maize and wheat in Brazil. Plant Soil 331:413-425. https://doi. org/10.1007/s11104-009-0262-0 
Hungria M (2011) Inoculação com Azospirillum brasilense: inovação em rendimento a baixo custo. Circular Técnica 325. Embrapa Soja, Londrina, p. 36. ISSN 1516-781X

Hungria M, Nogueira MA, Araujo RS (2013) Co-inoculation of soybeans and common beans with rhizobia and azospirilla: strategies to improve sustainability. Biol Fertil Soils 49:791-801. https://doi.org/10.1007/ s00374-012-0771-5

Hungria M, Nogueira MA, Araujo RS (2015) Soybean seed co-inoculation with Bradyrhizobium spp. and Azospirillum brasilense: a new biotechnological tool to improve yield and sustainability. Am J Plant Sci 6:811-817. https://doi.org/10.4236/ajps.2015.66087

Hungria M, Nogueira MA, Araujo RS (2016) Inoculation of Brachiaria spp. with the plant growth-promoting bacterium Azospirillum brasilense: an environment-friendly component in the reclamation of degraded pastures in the tropics. Agric Ecosyst Environ 221:125-131. https://doi. org/10.1016/j.agee.2016.01.024

Imada EL, Santos AP, Oliveira ALM, Hungria M, Rodrigues EP (2017) Indole3-acetic acid production via the indole-3-pyruvate pathway by plant growth promoter Rhizobium tropici CIAT 899 is strongly inhibited by ammonium. Res Microbiol 168:283-292. https://doi.org/10.1016/j. resmic.2016.10.010

IPCC (2014) Climate change 2014: impacts, adaptation, and vulnerability. http://ipcc-wg2.gov/AR5/report/full-report. Accessed 01 Jan 2018

Jozefczak M, Bohler S, Schat H, Horemans N, Guisez Y, Remans T, Vangronsveld J, Cuypers A (2015) Both the concentration and redox state of glutathione and ascorbate influence the sensitivity of arabidopsis to cadmium. Ann Bot 116:601-612. https://doi.org/10.1093/aob/mcv075

Juge C, Prévost D, Bertrand A, Bipfubusa M, Chalifou FP (2012) Growth and biochemical responses of soybean to double and triple microbial associations with Bradyrhizobium, Azospirillum and arbuscular mycorrhizae. Appl Soil Ecol 61:147-157. https://doi.org/10.1016/j.apsoil.2012.05.006

Jung S, Kernodle SP, Scandalios JG (2001) Differential antioxidant responses to norflurazon-induced oxidative stress in maize. Redox Rep 6:311-317. https://doi.org/10.1179/135100001101536454

Kauffmann S, Legrand M, Geoffroy P, Fritig B (1987) Biological function of "pathogenesis-related" proteins: four PR proteins of tobacco have 1,3- $\beta$-glucanase activity. EMBO J 6:3209-3212. https://doi. org/10.1002/j.1460-2075.1987.tb02637.X

Kawagoe Y, Shiraishi S, Kondo H, Yamamoto S, Aoki Y, Suzuki S (2015) Cyclic lipopeptide iturin A structure-dependently induces defense response in Arabidopsis plants by activating SA and JA signaling pathways. Biochem Biophys Res Commun 460:1015-1020. https://doi.org/10.1016/j. bbrc.2015.03.143

Khalid M, Bilal M, Hassani D, Iqbal N, Wang H, Huang D (2017) Mitigation of salt stress in white clover (Trifolium repens) by Azospirillum brasilense and its inoculation effect. Bot Stud 58:5. https://doi.org/10.1186/ s40529-016-0160-8

Khan MR, Kounsar K, Hamid A (2002) Effect of certain rhizobacteria and antoagonistic fungi on root-nodulation and root-knot nematode disease of green gram. Nematol Mediterr 30:85-89

Kim Y-C, Glick BR, Bashan Y, Ryu C-M (2012) Enhancement of plant drought tolerance by microbes. In: Aroca R (ed) Plant responses to drought stress: from morphological to molecular features. Springer Verlag, Berlin, pp 383-413. ISBN 978-3-642-32653-0

Kim K, Jang YJ, Lee SM, Oh BT, Chae JC, Lee KJ (2014) Alleviation of salt stress by Enterobacter sp. EJ01 in tomato and Arabidopsis is accompanied by up-regulation of conserved salinity responsive factors in plants. Mol Cells 37:109-117. https://doi.org/10.14348/molcells.2014.2239

Lamb C, Dixon RA (1997) The oxidative burst in plant disease resistance. Annu Rev Plant Physiol Plant Mol Biol 48:251-275. https://doi.org/10.1146/ annurev.arplant.48.1.25

León IP, Montesano M (2013) Activation of defense mechanisms against pathogens in mosses and flowering plants. Int J Mol Sci 14:3178-3200. https://doi.org/10.3390/ijms14023178

Lesk C, Rowhani P, Ramankutty N (2016) Influence of extreme weather disasters on global crop production. Nature 529:84-87. https://doi. org/10.1038/nature16467

Lim JH, Kim SD (2013) Induction of drought stress resistance by multifunctional PGPR Bacillus licheniformis K11 in pepper. Plant Pathol J 29:201-208. https://doi.org/10.5423/PPJ.SI.02.2013.0021
Lima E, Boddey RM, Döbereiner J (1987) Quantification of biological nitrogen fixation associated with sugarcane using a ${ }^{15} \mathrm{~N}$ aided nitrogen balance. Soil Biol Biochem 19:165-170

Lopes MS, Araus JL, van Heerden PDR, Foyer CH (2011) Enhancing drought tolerance in C4 crops. J Exp Bot 62:3135-3153. https://doi.org/10.1093/ jxb/err105

Lorenzo O, Solano R (2005) Molecular players regulating the jasmonate signalling network. Curr Opin Plant Biol 8:532-540. https://doi.org/10.1016/j. pbi.2005.07.003

Lugtenberg B, Kamilova F (2009) Plant-growth-promoting rhizobacteria. Annu Rev Microbiol 63:541-556. https://doi.org/10.1146/annurev. micro.62.081307.162918

Malamy J, Carr JP, Klessig DF, Raskin I (1990) Salicylic acid: a likely endogenous signal in the resistance response of tobacco to viral infection. Science 250(4983):1002-1004. https://doi.org/10.1126/science.250.4983.1002

Marks BB, Megías M, Ollero FJ, Nogueira MA, Araujo RS, Hungria M (2015) Maize growth promotion by inoculation with Azospirillum brasilense and metabolites of Rhizobium tropici CIAT 899 enriched on lipo-chitooligossacharides (LCOs). AMB Express 5:71. https://doi.org/10.1186/ s13568-015-0154-z

Marulanda A, Porcel R, Barea JM, Azcón R (2007) Drought tolerance and antioxidant activities in lavender plants colonized by native droughttolerant or drought-sensitive Glomus species. Microb Ecol 54:543-552. https://doi.org/10.1007/s00248-007-9237-y

McArthur JW, McCord GC (2017) Fertilizing growth: agricultural inputs and their effects in economic development. J Dev Econ 127:133-152. https://doi.org/10.1016/j.jdeveco.2017.02.007

Méndez-Gómez M, Castro-Mercado E, Alexandre G, García-Pineda E (2015) Oxidative and antioxidative responses in the wheat-Azospirillum brasilense interaction. Protoplasma 253:477-486. https://doi.org/10.1007/ s00709-015-0826-1

Morris SW, Vernooij B, Titatarn S, Starret M, Thomas S, Wiltse CC, Frederiksen RA, Bhandhufalck A, Hulbert S, Uknes S (1998) Induced resistance responses in maize. Mol Plant-Microbe Interact 11:643-658. https://doi. org/10.1094/MPMI.1998.11.7.643

Munns R, Tester M (2008) Mechanisms of salinity tolerance. Annu Rev Plant Bio 59:651-681. https://doi.org/10.1146/annurev.arplant.59.032607.092911

Mutava RN, Prince SJK, Syed NH, Song L, Valliyodan B, Chen W, Nguyen HT (2015) Understanding abiotic stress tolerance mechanisms in soybean: a comparative evaluation of soybean response to drought and flooding stress. Plant Physiol Biochem 86:109-120. https://doi.org/10.1016/j. plaphy.2014.11.010

Nabti E, Sahnoune M, Ghoul M, Fischer D, Hofmann A, Rothballer M, Schimid M, Hartmann A (2009) Restoration of growth of durum wheat (Triticum durum var. waha) under saline conditions due to inoculation with the rhizosphere bacterium Azospirillum brasilense $\mathrm{NH}$ and extracts of the marine alga Ulva lactuca. J Plant Growth Regul 29:6-22. https://doi. org/10.1007/s00344-009-9107-6

Ngumbi E, Kloepper J (2016) Bacterial-mediated drought tolerance: current and future prospects. Appl Soil Ecol 105:109-125. https://doi. org/10.1016/j.apsoil.2016.04.009

Nuccio ML, Rhodest D, McNeil SD, Hanson AD (1999) Metabolic engineering of plants for osmotic stress resistance. Curr Opin Plant Biol 2:128-134. https://doi.org/10.1016/S1369-5266(99)80026-0

Okon Y, Heytler PG, Hardy RW (1983) N Fixation by Azospirillum brasilense and its incorporation into host Setaria italica. Appl Environ Microbiol 46:694-697

Okon Y, Labandera-Gonzalez CA (1994) Agronomic applications of Azospirillum: an evaluation of 20 years worldwide field inoculation. Soil Biol Biochem 26:1591-1601. https://doi.org/10.1016/0038-0717(94)90311-5

Okon Y, Labandera-Gonzales C, Lage M, Lage P (2015) Agronomic applications of Azospirillum and other PGPR. In: de Brujin FJ (ed) Biological nitrogen fixation. Wiley, Hoboken. https://doi.org/10.1002/9781119053095.ch90

Ozyigit II, Filiz E, Vatansever R, Kurtoglu KY, Koc I, Öztürk MX, Anjum NA (2016) Identification and comparative analysis of $\mathrm{H}_{2} \mathrm{O}_{2}$-scavenging enzymes (ascorbate peroxidase and glutathione peroxidase) in selected plants employing bioinformatics approaches. Front Plant Sci 7:1-23. https:// doi.org/10.3389/fpls.2016.00301

Pajerowska-Mukhtar KM, Emerine DK, Mukhtar MS (2013) Tell me more: roles of NPRs in plant immunity. Trends Plant Sci 18:402-411. https://doi. org/10.1016/j.tplants.2013.04.004 
Pereg L, Luz E, Bashan Y (2016) Assessment of affinity and specificity of Azospirillum for plants. Plant Soil 399:389-414. https://doi.org/10.1007/ s11104-015-2778-9

Pérez-Montaño F, Alías-Villegas C, Bellogín RA, del Cerro P, Expuny MR, Jiménez-Guerrero I, López-Baena FJ, Ollero FJ, Cubo T (2014) Plant growth promotion in cereal and leguminous agricultural important plants: from microorganism capacities to crop production. Microbiol Res 169:325-336. https://doi.org/10.1016/j.micres.2013.09.011

Pieterse CMJ, Van der Does D, Zamioudis C, Leon-Reyes A, Van Wess SCM (2012) Hormonal modulation of plant immunity. Annu Rev Cell Dev Biol 28:489-521. https://doi.org/10.1146/annurev-cellbio-092910-154055

Pieterse CMJ, Zamioudis C, Berendsen RL, Weller DM, Van Wees SCM, Bakker PAHM (2014) Induced systemic resistance by beneficial microbes. Annu Rev Phytopathol 52:347-375. https://doi.org/10.1146/ annurev-phyto-082712-102340

Pieterse CMJ, Van Wees SCM (2015) Induced disease resistance. In: Lugtenberg $B$ (ed) Principles of plant-microbe interactions. Springer, Berlin, pp 123-133. https://doi.org/10.1007/978-3-319-08575-3_14

Puente ML, Gualpa JL, Lopez GA, Molina RM, Carletti SM, Cassán FD (2017) The benefits of foliar inoculation with Azospirillum brasilense in soybean are explained by an auxin signaling model. Symbiosis (Online). https://doi. org/10.1007/s13199-017-0536-x

Reis VM, Baldani JI, Baldani VLD, Döbereiner J (2000) Biological nitrogen fixation in graminae and palm trees. Crit Rev Plant Sci 19(3):227-247. https://doi.org/10.1016/S0735-2689(00)80003-9

Rodríguez-Salazar J, Suárez R, Caballero-Mellado J, Iturriaga G (2009) Trehalose accumulation in Azospirillum brasilense improves drought tolerance and biomass in maize plants. FEMS Microbiol Lett 296:52-59. https://doi. org/10.1111/j.1574-6968.2009.01614.x

Romero AM, Correa OS, Moccia S, Rivas JG (2003) Effect of Azospirillum-mediated plant growth promotion on the development of bacterial diseases on fresh-market and cherry tomato. J Appl Microbiol 95:832-838. https://doi.org/10.1046/j.1365-2672.2003.02053.x

Roser M, Ritchie H (2017) Fertilizers and Pesticides. Oxford: Our World in Data. https://ourworldindata.org/fertilizer-and-pesticides/. Accessed on 01 Jan 2018

Sá JCM, Lal R, Cerri CC, Lorenz K, Hungria J, Carvalho PCC (2017) Low-carbon agriculture in South America to mitigate global climate change and advance food security. Environ Int 98:102-112. https://doi. org/10.1016/j.envint.2016.10.020

Saeed M, Ilyas N, Mazhar R, Bibi F, Batool N (2016) Drought mitigation potential of Azospirillum inoculation in canola (Brassica napus). J Appl Bot Food Qual 278:270-278. https://doi.org/10.5073/JABFQ.2016.089.035

Saharan BS, Nehra V (2011) Plant growth promoting rhizobacteria: a critical review. Life Sci Med Res 2011:1-30

Sahoo RK, Ansari MW, Pradhan M, Dangar TK, Mohanty S, Tuteja N (2014) Phenotypic and molecular characterization of native Azospirillum strains from rice fields to improve crop productivity. Protoplasma 251:943-953. https://doi.org/10.1007/s00709-013-0607-7

Sandhya V, Ali SZ, Grover M, Reddy G, Venkateswarlu B (2010) Effect of plant growth promoting Pseudomonas spp. on compatible solutes, antioxidant status and plant growth of maize under drought stress. Plant Growth Regul 62:21-30. https://doi.org/10.1007/s10725-010-9479-4

Sankari JU, Dinakar S, Sekar C (2011) Dual effect of Azospirillum exopolysaccharides (EPS) on the enhancement of plant growth and biocontrol of blast (Pyricularia oryzae) disease in upland rice (var. ASD-19). J Phytol 3:16-19. ISSN 2075-6240

Sarma BK, Yadav SK, Singh DP, Singh HB (2012) Rhizobacteria mediated induced systemic tolerance in plants: prospects for abiotic stress management. In: Maheshwari DK (ed) Bacteria in agrobiology: stress management. Springer, Berlin, pp 225-238. https://doi. org/10.1007/978-3-642-23465-1_11

Sarma RK, Saikia R (2014) Alleviation of drought stress in mung bean by strain Pseudomonas aeruginosa GGRJ21. Plant Soil 377:111-126. https://doi. org/10.1007/s11104-013-1981-9

Scandalios JG, Guan L, Polidoros AN (1997) Catalases in plants: gene structure, properties, regulation, and expression. In: Scandalios JG (ed) Oxidative stress and the molecular biology of antioxidant defenses. New York: Cold Spring Harbor Laboratory, pp 343-406. ISSN 0196-6006

Segarra G, Van Der Ent S, Trillas I, Pieterse CMJ (2009) MYB72, a node of convergence in induced systemic resistance triggered by a fungal and a bacterial beneficial microbe. Plant Biol 11:90-96. https://doi. org/10.1111/j.1438-8677.2008.00162.x

Shanker AK, Maheswari M, Yadav SK, Desai S, Bhanu D, Attal NB, Venkateswarlu B (2014) Drought stress responses in crops. Funct Integr Genom 14:11-22. https://doi.org/10.1007/s10142-013-0356-x

Sharma P, Jha AB, Dubey RS, Pessarakli M (2012) Reactive oxygen species, oxidative damage, and antioxidative defense mechanism in plants under stressful conditions. J Bot 2012:1-26. https://doi. org/10.1155/2012/217037

Shigeoka S, Maruta T (2014) Cellular redox regulation, signaling, and stress response in plants. Biosci Biotechnol Biochem 78:1457-1470. https:// doi.org/10.1080/09168451.2014.942254

Silva M de A, Santos CM dos, Vitorino H dos S, Lima Rhein AF de (2014) Pigmentos fotossintéticos e índice SPAD como descritores de intensidade do estresse por deficiência hídrica em cana-de-açúcar. Biosci J 173-181. ISSN 1981-3163

Simova-Stoilova L, Demirevska K, Petrova T, Tsenov N, Feller U (2008) Antioxidative protection in wheat varieties under severe recoverable drought at seedling stage. Plant, Soil Environ 54:529-536

Smirnoff N (1993) The role of active oxygen in the response of plants to water deficit and desiccation. New Phytol 125:27-58. https://doi. org/10.1111/j.1469-8137.1993.tb03863.x

Souza GM, Catuchi TA, Bertolli SC, Soratto RP (2013) Soybean under water deficit: physiological and yield responses. In: Board JE (ed) A Comprehensive Survey of International Soybean Research-Genetics, Physiology, Agronomy and Nitrogen Relationships. InTech, pp 273-298. https://doi. org/10.5772/54269

Spaepen S, Bossuyt S, Engelen K, Marchal K, Vanderleyden J (2014) Phenotypical and molecular responses of Arabidopsis thaliana roots as a result of inoculation with the auxin-producing bacterium Azospirillum brasilense. New Phytol 201:850-861. https://doi.org/10.1111/nph.12590

Spaepen S, Vanderleyden J (2015) Auxin signaling in Azospirillum brasilense: a proteome analysis. In: de Bruijn FJ (ed) Biological nitrogen fixation. Wiley, Hoboken, pp 937-940. https://doi.org/10.1002/9781119053095. ch91

Spoel SH (2003) NPR1 modulates cross-talk between salicylate- and jasmonate-dependent defense pathways through a novel function in the cytosol. Plant Cell 15:760-770. https://doi.org/10.1105/tpc.009159

Stein E, Molitor A, Kogel KH, Waller F (2008) Systemic resistance in Arabidopsis conferred by the mycorrhizal fungus Piriformospora indica requires jasmonic acid signaling and the cytoplasmic function of NPR1. Plant Cell Physiol 49:1747-1751. https://doi.org/10.1093/pcp/pcn147

Strzelczyk E, Kampert M, Li CY (1994) Cytokinin-like substances and ethylene production by Azospirillum in media with different carbon sources. Microbiol Res 149:55-60. https://doi.org/10.1016/ S0944-5013(11)80136-9

Sudha G, Ravishankar GA (2002) Involment and interaction of various signaling compounds on the plant metabolic events during defense response, resistance to stress factors, formation of secondary metabolites and their molecular aspects. Plant Cell Tissue Organ Cult 71:181-212. https://doi.org/10.1023/A:1020336626361

Tarrand JJ, Krieg NR, Döbereiner J (1978) A taxonomic study of the Spirillum lipoferum group, with the descriptions of a new genus, Azospirillum gen. nov. and two species Azospirillum lipoferum (Beijerinck) comb. nov. and Azospirillum brasilense sp. nov. Can J Microbiol 24:967-980

Tien TM, Gaskins MH, Hubbell DH (1979) Plant growth substances produced by Azospirillum brasilense and their effect on the growth of Pearl Millet (Pennisetum americanum L.). Appl Environ Microbiol 37:1016-1024

Timmusk S, Wagner EG (1999) The plant-growth-promoting rhizobacterium Paenibacillus polymyxa induces changes in Arabidopsis thaliana gene expression: a possible connection between biotic and abiotic stress responses. Mol Plant-Microbe Interact 12:951-959. https://doi. org/10.1094/MPMI.1999.12.11.951

Torsethaugen G, Pitcher LH, Zilinskas BA, Pell EJ (1997) Overproduction of ascorbate peroxidase in the tobacco chloroplast does not provide protection against ozone. Plant Physiol 114:529-537. https://doi. org/10.1104/pp.114.2.529

Tortora ML, Díaz-Ricci JC, Pedraza RO (2011) Azospirillum brasilense siderophores with antifungal activity against Colletotrichum acutatum. Arch Microbiol 193:275-286. https://doi.org/10.1007/s00203-010-0672-7 
Turan M, Gulluce M, von Wirén N, Sahin F (2012) Yield promotion and phosphorus solubilization by plant growth-promoting rhizobacteria in extensive wheat production in Turkey. J Plant Nutr Soil Sci 175:818-826. https://doi.org/10.1002/jpln.201200054

Uknes S, Mauch-Mani B, Moyer M, Potter S, Williams S, Dincher S, Chandler D, Slusarenko A, Ward E, Ryals J (1992) Acquired resistance in Arabidopsis. Plant Cell 4:645-656. https://doi.org/10.1105/tpc.4.6.645

Upadhyay SK, Singh JS, Saxena AK, Singh DP (2012) Impact of PGPR inoculation on growth and antioxidant status of wheat under saline conditions. Plant Biol 14:605-611. https://doi.org/10.1111/j.1438-8677.2011.00533.x

van Loon LC, van Strien EA (1999) The families of pathogenesis-related proteins, their activities, and comparative analysis of PR-1 type proteins. Physiol Mol Plant Pathol 55:85-97. https://doi.org/10.1006/ pmpp.1999.0213

van Loon LC, Bakker P (2005) Induced systemic resistance as a mechanism of disease suppression by rhizobacteria. In: PGPR: Biocontrol and biofertilization. The Netherlands: Springer, pp 39-66. https://doi. org/10.1007/1-4020-4152-7_2

van Loon LC, Rep M, Pieterse CMJ (2006) Significance of inducible defenserelated proteins in infected plants. Annu Rev Phytopathol 44:135-162. https://doi.org/10.1146/annurev.phyto.44.070505.143425

van Loon LC (2007) Plant responses to plant growth-promoting rhizobacteria. Eur J Plant Pathol 119:243-254. https://doi.org/10.1007/ s10658-007-9165-1

van Peer R, Niemann GJ, Schippers B (1991) Induced resistence and phytoalexin accumulation in biological control of Fusarium wilt of carnation by Pseudomonas sp. strain WCS417r. Phytopathology 81:728-734. https://doi.org/10.1094/Phyto-81-728

Vurukonda SSKP, Vardharajula S, Shrivastava M, SkZ A (2016) Enhancement of drought stress tolerance in crops by plant growth promoting rhizobacteria. Microbiol Res 184:13-24. https://doi.org/10.1016/j. micres.2015.12.003

Wang CJ, Yang W, Wang C, Gu C, Niu DD, Liu HX, Wang UP, Guo JH (2012) Induction of drought tolerance in cucumber plants by a consortium of three plant growth-promoting rhizobacterium strains. PLOS ONE 7:1-10. https://doi.org/10.1371/journal.pone.0052565
Wasternack C (2007) Jasmonates: an update on biosynthesis, signal transduction and action in plant stress response, growth and development. Ann Bot 100:681-697. https://doi.org/10.1093/aob/mcm079

Wei G, Kloepper W, Tuzun S (1991) Induction os systemic resistance of cucumber to Colletotrichum orbiculare by select of plant growth-promoting rhizobacteria. Phytopathology 81:1508-1512. https://doi.org/10.1094/ Phyto-81-1508

Wisniewski-Dyé F, Lozano L, Acosta-Cruz E, Borland S, Drogue B, PrigentCombaret C, Rouy Z, Barbe V, Herrera AM, González V, Mavingui P (2012) Genome sequence of Azospirillum brasilense CBG497 and comparative analyses of Azospirillum core and accessory genomes provide insight into niche adaptation. Genes (Basel) 3:576-602. https://doi. org/10.3390/genes3040576

Yan Z, Reddy MS, Ryu CM, McInroy J, Wilson M, Kloepper W (2002) Induced systemic protection against tomato late blight elicited by plant growthpromoting rhizobacteria. Phytopathology 92:1329-1333. https://doi. org/10.1094/PHYTO.2002.92.12.1329

Yang J, Kloepper JW, Ryu CM (2009) Rhizosphere bacteria help plants tolerate abiotic stress. Trends Plant Sci 14:1-4. https://doi.org/10.1016/j. tplants.2008.10.004

Yanni YG, Dazzo FB (2015) Occurrence and ecophysiology of the natural endophytic Rhizobium-rice association and translational assessment of its biofertilizer performance within the Egypt nile delta. In: de Bruijn FJ (ed) Biological nitrogen fixation. Wiley, Hoboken, pp 747-756. https:// doi.org/10.1002/9781119053095.ch111

Yasuda M, Isawa T, Shinozaki S, Minamisawa K, Nakashita H (2009) Effects of colonization of a bacterial endophyte, Azospirillum sp. B510, on disease resistance in rice. Biosci Biotechnol Biochem 73:2595-2599. https://doi. org/10.1271/bbb.90402

Zahedi AM, Fazeli I, Zavareh M, Dorry H, Gerayeli N (2012) Evaluation of the sensitive components in seedling growth of common bean (Phaseolus vulgaris L.) affected by salinity. Asian J Crop Sci 4:159-164. https://doi. org/10.3923/ajcs.2012.159.164

\section{Submit your manuscript to a SpringerOpen ${ }^{\odot}$ journal and benefit from:}

- Convenient online submission

- Rigorous peer review

- Open access: articles freely available online

- High visibility within the field

- Retaining the copyright to your article

Submit your next manuscript at $\boldsymbol{\nabla}$ springeropen.com 